\title{
Fiscal Sustainability And Fiscal Reaction Functions In The US And UK
}

\author{
Philippe Burger, University of the Free State, South Africa
}

\begin{abstract}
Following the 2008/9 financial and economic crisis, public debt/GDP ratios in several countries rose to their highest levels in 40 years. Also in the US and the UK did the public debt/GDP ratios increase significantly, thereby putting the spotlight again on fiscal sustainability. Based on past behaviour, this article asks whether fiscal policy in these two countries is likely to be sustainable. The article investigates how the US and UK governments, by changing their deficits, react to changes in their debt positions. To do this, the article estimates fiscal reaction functions using Smooth Transition Regressions. It finds that based on past behaviour, fiscal policy in both the US and UK can be expected to remain sustainable. Based on the same past behaviour, and assuming this behaviour will continue in the future, the article also calculates the levels to which the public debt/GDP ratios in the US and UK can be expected to converge.
\end{abstract}

Keywords: Fiscal Sustainability; Fiscal Reaction Function; Public Debt; Deficits

\section{INTRODUCTION}

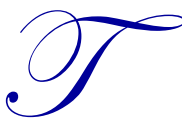

he response of many governments to the 2008/9 financial and economic crisis resulted in public debt/GDP ratios in several countries rising to their highest levels in 40 years. At a projected $100 \%$ of GDP for 2011, the US gross public debt/GDP ratio is reaching a level not seen since the Reagan deficit-and-debt days of the 1980s, while in the UK, the gross public debt/GDP ratio is projected to reach 90\%, a level not seen since the late $1960 \mathrm{~s}^{1}$ (OECD estimates).

This article focuses on the US and the UK using OECD data. ${ }^{2}$ In the UK, the Cameron government places a high premium on reigning in public debt. Thus, one would expect UK fiscal policy to be sustainable. This is often contrasted with the more liberal attitude of the Obama administration in the US that first wants to stabilise the economy and thereafter stabilise the public debt burden. Many commentators on Mr Obama's right view the latter behaviour as fiscally unsustainable. This view by the fiscally concerned is not new and recalls the concerns expressed in the 1980s and early 1990s about the higher public debt/GDP ratios that originated during the Reagan administration and also followed a significant recession, that of the early 1980s. Thus, using the past, as a guide to what can be expected in the future about the behaviour of the UK and US governments toward their respective debt burdens, raise a series of questions:

1. What was the fiscal reaction (if any) of the US and UK to their respective public debt burdens?

2. If they did react, was their reaction large enough to ensure fiscal sustainability?

3. If their debt/GDP ratios were on a sustainable path, and thus not expected to explode, and assuming that past behaviour will continue in future, to which levels can the individual public debt/GDP ratios be expected to converge in future?

\footnotetext{
${ }^{1}$ All figures cited in the article refer to general government level.

${ }^{2}$ Though data series of longer duration are available for these countries, the data in the OECD database are uniform, with all series subjected to the same transformations and calculated in the same manner.
}

(C) 2012 The Clute Institute http://www.cluteinstitute.com/ 
Bohn (2010, 2007, 1998 and 1995), at various times, considered whether or not fiscal policy in the US has been sustainable. He argues that fiscal policy in the US is sustainable, but in his 2010 paper, he does caution that this might change if the US government's indebtedness becomes too high. This paper extends on his analysis by applying Smooth Transition Regression (STR) modelling to allow for the possibility that, depending on the debt/GDP level, governments react differently to their debt/GDP ratio. Rarely do governments exhibit the same behaviour over a full sample period. More specifically, the paper argues that it is possible that governments did not have the same level of awareness of fiscal pressure throughout the sample period, simply because fiscal pressure was not always seen as a problem. Thus, fiscal reaction is limited to those times when the debt/GDP ratio is considered to be beyond a desired limit. ${ }^{3}$ As the analysis below shows, there is evidence that this has indeed been the case in the US and UK.

\section{Whence Fiscal Reaction Functions?}

Fiscal reaction functions usually specify the reaction of the primary balance (i.e., the budget balance excluding interest payments), expressed as a ratio of GDP, to changes in the one-period lagged public debt/GDP ratio (cf. Bohn, 2007, 1998). The fiscal reaction function is a behavioural function where government's behaviour is informed by its budget constraint and the budget identity (cf. Bohn, 1995, 1998, 2007; Gali and Perotti, 2003; De Mello, 2005). The budget identity of government is specified as:

$D_{t}=D_{t-1}+i_{t} D_{t-1}-B_{t}$

where $\mathrm{D}=$ Public debt, $\mathrm{i}=$ Nominal interest rate on government bonds and B = Primary balance (+ surplus; deficit). Equation (1) can be used to derive Equation (2):

$\Delta(\mathrm{D} / \mathrm{Y})_{\mathrm{t}}=\left(\left(\mathrm{r}_{\mathrm{t}}-\mathrm{g}_{\mathrm{t}}\right) /\left(1+\mathrm{g}_{\mathrm{t}}\right)\right)(\mathrm{D} / \mathrm{Y})_{\mathrm{t}-1}-(\mathrm{B} / \mathrm{Y})_{\mathrm{t}}$

where $r=$ Real interest rate, $g=$ Real economic growth rate and $\mathrm{Y}=$ Nominal GDP. Using Equation (2), one can state the primary deficit required to ensure that the debt/GDP ratio remains unchanged (i.e., $\Delta(\mathrm{D} / \mathrm{Y})_{\mathrm{t}}=0$ ):

$(\mathrm{B} / \mathrm{Y})_{\mathrm{t}}=\left(\left(\mathrm{r}_{\mathrm{t}}-\mathrm{g}_{\mathrm{t}}\right) /\left(1+\mathrm{g}_{\mathrm{t}}\right)\right)(\mathrm{D} / \mathrm{Y})_{\mathrm{t}-1}$

Therefore, Equation (3) implies that if a government decides to keep its public debt/GDP ratio constant, it would implement the following rule:

$(\mathrm{B} / \mathrm{Y})_{\mathrm{t}}^{\text {Required }}=\alpha_{\mathrm{t}}^{*}(\mathrm{D} / \mathrm{Y})_{\mathrm{t}-1}=\left(\left(\mathrm{r}_{\mathrm{t}}-\mathrm{g}_{\mathrm{t}}\right) /\left(1+\mathrm{g}_{\mathrm{t}}\right)\right)(\mathrm{D} / \mathrm{Y})_{\mathrm{t}-1}$

Thus, $\alpha_{t}^{*}$ equals $\left(r_{t}-g_{t}\right) /\left(1+g_{t}\right)$. This 'fiscal rule' - or 'required fiscal reaction function' - can be compared to the actual behavioural relationship (i.e., an estimated fiscal reaction function). To establish the actual behaviour of government, and thus, what value $\alpha$ took, one can estimate a fiscal reaction function of the form:

$(\mathrm{B} / \mathrm{Y})_{\mathrm{t}}^{\text {Actual }}=\alpha(\mathrm{D} / \mathrm{Y})_{\mathrm{t}-1}+\varepsilon_{\mathrm{t}}$

To allow for inertia in government behaviour, a lag of the primary balance is added to Equation (5) (De Mello, 2005:10). The output gap, $\hat{y}$, is added to allow for short-run demand stabilisation with a positive parameter indicating a counter-cyclical policy (Bohn, 1998:951; De Mello, 2005:10, also see Taylor, 2000). Lastly, a constant, $\alpha_{1}$, is added to Equation (5) to allow for an explicit or implicit debt/GDP target that may not equal zero. The basic fiscal reaction function is then specified as:

$(\mathrm{B} / \mathrm{Y})_{\mathrm{t}}^{\text {Actual }}=\alpha_{1}+\alpha_{2}(\mathrm{~B} / \mathrm{Y})_{\mathrm{t}-1}{ }^{\text {Actual }}+\alpha_{3}(\mathrm{D} / \mathrm{Y})_{\mathrm{t}-1}+\alpha_{4}(\hat{\mathrm{y}})_{\mathrm{t}-1}$

\footnotetext{
${ }^{3}$ This, of course, also implies that not only may a debt/GDP ratio be seen as exceeding a safe limit, but at the other end of the spectrum, there might also be a ratio below which the debt/GDP ratio is seen as too low.
} 
Taking Equations (4) and (6), one can consider the interaction of the required and actual reaction functions in establishing whether or not fiscal policy is sustainable in the longer run.

Whether or not the debt/GDP ratio will stabilise (i.e., reach an equilibrium) or explode (either in a positive or negative direction) depends on the parameters $\alpha_{t}^{*}$ in Equation (4) and $\alpha_{2}$ and $\alpha_{3}$ in Equation (6). If $\alpha_{t}^{*}<\alpha_{3} /\left(1-\alpha_{2}\right)$, the debt/GDP and primary balance/GDP ratios stabilise. The level at which the debt/GDP ratio will stabilise can be either positive or negative. To see this, take the unconditional expected values for $(\mathrm{B} / \mathrm{Y})_{\mathrm{t}}{ }^{\text {Actual }},(\mathrm{D} / \mathrm{Y})_{\mathrm{t}-1},(\hat{\mathrm{y}})_{\mathrm{t}-1}$ and $\alpha_{\mathrm{t}}{ }^{*}$ in Equations (4) and (6) and set $(\mathrm{B} / \mathrm{Y})_{\mathrm{t}}^{\text {Required }}=\mathrm{E}\left((\mathrm{B} / \mathrm{Y})_{\mathrm{t}}^{\text {Actual }}\right)$, while also noting that $\mathrm{E}(\hat{\mathrm{y}})_{\mathrm{t}-1}=0$ and $\alpha^{*}=\mathrm{E}\left(\alpha_{\mathrm{t}}{ }^{*}\right)$ and in equilibrium $\mathrm{E}\left((\mathrm{B} / \mathrm{Y})_{\mathrm{t}}{ }^{\text {Actual }}\right)=\mathrm{E}\left((\mathrm{B} / \mathrm{Y})_{\mathrm{t}-1}{ }^{\text {Actual }}\right)$. This yields:

$(\mathrm{D} / \mathrm{Y})^{\text {Stable }}=-\left(\alpha_{1} /\left(1-\alpha_{2}\right)\right) /\left(\left(\alpha_{3} /\left(1-\alpha_{2}\right)-\alpha^{*}\right)\right.$

In equilibrium, Equation (6) also becomes:

$(\mathrm{B} / \mathrm{Y})_{\mathrm{t}}^{\text {Actual }}=\alpha_{1} /\left(1-\alpha_{2}\right)+\left(\alpha_{3} /\left(1-\alpha_{2}\right)\right)(\mathrm{D} / \mathrm{Y})_{\mathrm{t}-1}+\left(\alpha_{4} /\left(1-\alpha_{2}\right)\right)(\hat{\mathrm{y}})_{\mathrm{t}-1}$

In comparing Equation (8) with Equation (4), it can be seen that if $\alpha^{*}<\alpha_{3} /\left(1-\alpha_{2}\right)$, then the actual reaction of government to its debt/GDP ratio is larger than the required reaction, which will then ensure that the debt/GDP ratio and the primary balance/GDP ratio stabilises. Also note that if $\alpha_{1}$ is negative (positive), the debt/GDP ratio will stabilise at a positive (negative) value.

If $\alpha^{*}>\alpha_{3} /\left(1-\alpha_{2}\right)$, and unless the debt/GDP and the primary balance/GDP ratios find themselves at their equilibrium values, the debt/GDP ratio (and the primary balance/GDP ratio) will explode, either in a positive or negative direction. The explosion will be positive if the initial debt/GDP ratio exceeds the equilibrium debt/GDP ratio, and negative otherwise. If $\alpha^{*}=\alpha_{3} /\left(1-\alpha_{2}\right)$, the debt/GDP and the primary balance/GDP ratios will be firstdifference stationary. Note that these conditions about $\alpha_{1}, \alpha_{3}$ and $\alpha^{*}$ hold whether $\alpha^{*}$ and $\alpha_{3}$ are negative or positive. (Also see Bohn, 2007:1844.)

Note that the concept of fiscal sustainability addressed here considers fiscal sustainability on the level of government's overall, summative reaction to its debt position. A more fundamental analysis would consider the underlying long-term forces driving government expenditure and taxation. These forces would include long-term demographic factors that, for instance, influence social welfare and health-care expenditure or resource depletion that influences the tax base. However, these topics, though highly relevant, cannot all be addressed in a single article.

\section{The Stationarity Of The Debt/GDP Ratio}

One problematic issue regarding the behaviour of the debt/GDP ratio and the primary balance/GDP ratio is their expected near-unit-root behaviour. Consider Equation (9), which is a transformed version of Equation (2):

$(\mathrm{D} / \mathrm{Y})_{\mathrm{t}}=\left(\left(1+\mathrm{r}_{\mathrm{t}}\right) /\left(1+\mathrm{g}_{\mathrm{t}}\right)\right)(\mathrm{D} / \mathrm{Y})_{\mathrm{t}-1}-(\mathrm{B} / \mathrm{Y})_{\mathrm{t}}$

Equation (9) can be used to show that even if the debt/GDP series is stationary, standard stationarity tests might find it difficult to reject the null hypothesis of a unit root (Bohn, 1998:955). For instance, if in Equation (9) $\mathrm{r}$ $=2 \%$ and $\mathrm{g}=4 \%$, then $\left(\left(1+\mathrm{r}_{\mathrm{t}}\right) /\left(1+\mathrm{g}_{\mathrm{t}}\right)\right)=0.98$, which, though not a unit root, is very close to a unit root. However, even in cases where $\left(\left(1+r_{t}\right) /\left(1+g_{t}\right)\right) \geq 1$, government may set the primary balance (i.e. the second term on the righthand side of Equation (9)) to offset the effect of the first term on the right-hand side. This offsetting may render the debt/GDP ratio either level stationary (but still so close to a unit root that conventional stationarity tests fail to establish whether or not the series is stationary) or first-difference stationary.

However, despite the above difficulty, Bohn (1998) argues why the series should be accepted as stationary on economic grounds. His reasoning is based on the fact that in the US, the real interest rate paid by government has, for the most part of the $20^{\text {th }}$ century, been below the economic growth rate, a point Bohn (2010) recently repeated. Bohn (2007) further argues that one should not be overly concerned with the stationarity of the debt and 
deficit series (whether or not expressed as ratio to GDP) because, if by differencing these series any number of times they become stationary, then government satisfies its intertemporal budget constraint. Bohn, instead, argues for the use of 'error-correction-type policy reaction functions', such as the fiscal reaction function defined above. It is noteworthy that he does not explicitly control or account for the stationarity properties of the data in estimating these reaction functions. Favero and Marcellino (2005:759) are in agreement with Bohn when they argue in their article that:

As there are strong economic reasons to assume that all the seven variables [which include government debt and the fiscal balance, expressed as ratios to GDP] are stationary, we will proceed under this assumption even though the outcome of augmented Dickey-Fuller unit root tests is mixed, likely due to the low power of these tests in samples as short as ours (42 observations). Text in [ ] is not in the original, but refers to the variables that the authors included.

This paper will follow the example of the above authors in not distinguishing between the stationarity or non-stationarity of the debt/GDP and deficit/GDP series employed in the paper.

\section{DATA AND METHOD}

Annual data for the US and the UK originate from the OECD database (2010). The sample period for the US is 1970-2008, while for the UK it is 1972-2008. Notice that the sample period runs up to 2008 so as not to include the current recession. Since the recuperation from the latest recession is still under way, including data for the recession will not fully capture the reaction of the governments to their increased debt/GDP ratios. Indeed, the analysis even considered limiting it to 2007 to exclude the recession completely, but since the financial crisis only fully registered toward the end of 2008, the analysis proceeded by including 2008 .

The debt variable used is general government gross financial liabilities outstanding, as a percentage of GDP. ${ }^{4}$ The primary balance measure is the cyclically-adjusted primary balance, as a percentage of potential GDP. The cyclically-adjusted primary balance addresses the shortcomings of the unadjusted primary balance by excluding the automatic stabilising effect of the business cycle from the primary balance. Excluding the effect of the business cycle from the cyclically-adjusted primary balance when estimating Equation (6) allows for a focus on how policy decisions (i.e., discretionary policy) change in reaction to the level of the debt/GDP ratio. The output gap data used also originates from the OECD database. ${ }^{5}$

The article presents estimates of Equation (6) using logistic STR models. The STR method was specifically designed to allow for non-linear behaviour in modelling relationships. Usually STR models are estimated for two or three regimes. For instance, two-regime models frequently refer to business cycle models where, during upswings, behaviour differs from downswings, or monetary reaction functions that allow for high and low inflation regimes. Three-regime models may also be used where behaviour near to the peaks and troughs of the cycles are similar, but different from behaviour in between peaks and troughs (Teräsvirta, 2004:224). This article explores the applicability of STR on the a priori expectation that government will react differently to a very high debt/GDP ratio than to a low debt/GDP ratio. For instance, a debt/GDP ratio increasing from $120 \%$ to $130 \%$ raises much more alarm and calls for much more serious intervention than one increasing from $20 \%$ to $30 \%$. According to Teräsvirta (2004:223) the standard STR model is defined as:

$$
\begin{aligned}
\mathrm{y}_{\mathrm{t}} & =\varphi^{\prime} \mathbf{z}_{\mathrm{t}}+\theta^{\prime} \mathbf{z}_{\mathrm{t}} \mathrm{G}\left(\gamma, \mathrm{c}, \mathrm{s}_{\mathrm{t}}\right)+\mathrm{u}_{\mathrm{t}} \\
& =\left(\varphi^{\prime}+\theta^{\prime} \mathrm{G}\left(\gamma, \mathrm{c}, \mathrm{s}_{\mathrm{t}}\right)\right) \mathbf{z}_{\mathrm{t}}+\mathrm{u}_{\mathrm{t}}, \mathrm{t}=1, \ldots \mathrm{T}
\end{aligned}
$$

\footnotetext{
${ }^{4}$ This article prefers using gross financial liabilities to net financial liabilities. Though the latter, on the face of it, might seem to reflect the real indebtedness of government, this might be misleading. When a government faces pressure to repay debt, many of its financial assets cannot be used to simply offset government debt. For instance, governments will and can rarely simply sell their holdings in public corporations, use their cash or call up loans to the private sector to repay public debt. Hence, the burden of repayment and servicing gross debt will, in most cases, fall on taxation. See Cecchetti et al. (2010:9n) who use the same justification for using gross liabilities.

${ }^{5}$ For a complete exposition on the OECD methodology to estimate cyclically-adjusted primary balances, potential GDP, and the corresponding output gaps, see Girouard and André (2005). 
where $\mathrm{z}$ is a vector of explanatory variables (including lagged dependent variables and exogenous variables); $\varphi$ and $\theta$ are parameter vectors, while $\mathrm{u}_{\mathrm{t}} \sim \operatorname{iid}\left(0 ; \sigma^{2}\right) . \mathrm{G}\left(\gamma, \mathrm{c}, \mathrm{s}_{\mathrm{t}}\right)$ is a transition function - it is a bounded function of the transition variable, $\mathrm{s}_{\mathrm{t}}$, continuous everywhere in the parameter space for any value of $\mathrm{s}_{\mathrm{t}} ; \gamma$ is a slope parameter of the transition function, while $\mathrm{c}$ is a vector of location parameters - it indicates at which value of the transition variable, $\mathrm{s}$, the transition occurs - with the transition function being a logistic function (Teräsvirta, 2004:223). In terms of Equation (6), $\mathrm{z}$ includes the lag of the primary balance, the debt/GDP ratio and the output gap. The transition variable, $\mathrm{s}$, is the debt/GDP ratio, while c indicates at which level of the debt/GDP ratio behaviour transitions from the first to the second regime (and in the case of a three-regime model, also from the second to the third regime). In the case of a two-regime model, the first regime would be characterised as a low debt/GDP regime, while the second regime would be a high debt/GDP regime. In a three-regime model, government might react to (too) low debt (first regime) and (too) high debt (third regime), while reacting moderately or not at all to debt that is considered not too low or too high (second regime).

Note that estimated parameters of the second regime should be interpreted as cumulative to the first regime. Thus, in the first regime, the response to change in $\mathrm{z}$ is $\varphi$, while in the second regime, it is $\varphi+\theta$. In addition, note that estimation also allows for setting $\varphi$ or $\theta$ of some of the variables equal to zero or for specifying that $\varphi=-\theta$. Setting the $\varphi$ of the debt/GDP ratio equal to zero in a two-regime model allows one to postulate that in the low debt/GDP regime, government does not react to changes in the debt/GDP ratio - it only does so once the debt/GDP ratio crosses into the high debt/GDP regime. Setting $\varphi=-\theta$ in a three-regime model allows for the possibility that government reacts to too low (first regime) and too high debt (third regime), but does not react to moderate debt (second regime).

Before an STR function can be estimated, one should first test for linearity. To do so, one estimates an auxiliary regression of the form (Teräsvirta 2004:226-7):

$\mathrm{Y}_{\mathrm{t}}=\beta_{0}^{\prime} \mathrm{Z}_{\mathrm{t}}+\Sigma_{\mathrm{j}=1}^{3} \beta_{j}^{\prime} \mathrm{z}_{\mathrm{t}}{ }^{*} \mathrm{~s}_{\mathrm{t}}^{\mathrm{j}}+\mathrm{u}_{\mathrm{t}}^{*}, \quad \mathrm{t}=1, \ldots \mathrm{T}$

where $u_{t}^{*}=u_{t}+R_{3}\left(\gamma, c, s_{t}\right) \theta^{\prime} \mathbf{z}_{t}$ with the remainder $R_{3}\left(\gamma, c, s_{t}\right)$. Using an LM-type test, one then tests the null hypothesis $\mathrm{H}_{0}=\beta_{1}=\beta_{2}=\beta_{3}=0$ because each $\beta_{\mathrm{j}}$, with $\mathrm{j}=1,2$, and 3 , is of the form $\gamma \beta_{\mathrm{j}}^{*}$ where $\beta_{\mathrm{j}}^{*}=0$ is a function of $\theta$ and $\mathrm{c}$. In the special case where $\mathrm{c}=0$ and $\beta_{2}=0$, there are two regimes, while in the case where $\mathrm{c}=0$ and $\beta_{1}=\beta_{3}=$ 0 , there are three regimes. In cases where $c \neq 0, \beta_{2}$ is closer to the null vector than $\beta_{1}$ and $\beta_{3}$ in the case of two regimes, while the reverse holds in the case of three regimes (Teräsvirta, 2004:227).

\section{ESTIMATION RESULTS}

This section presents the various versions of Equations (6), estimated with the STR modelling. The results are presented in Table 1. First, the analysis tested for linearity using the auxiliary regression discussed above (Equation (11)). Non-linearity was found for both countries. In the case of the US, the test indicated the presence of two regimes, while in the case of the UK, it detected three regimes. ${ }^{6}$ Hence, for the US, a two-regime model was estimated, while for the UK, a three-regime model was estimated.

None of the estimated relationships suffer from autocorrelation, though the error terms are not normally distributed. Eliminating the last observation (i.e., 2008) from the US and UK samples, to eliminate the rather large downward swing in the output gap following the outbreak of the financial crisis, restored normality to the US model, but not to the UK model. ${ }^{7}$ The adjusted R-squares of all models are high, in excess of 0.74 .

Table 1 also indicates restrictions on $\varphi$ or $\theta$ (i.e., which ones were set equal to zero or $\varphi=-\theta$ ). In the case of the US, the $\varphi$ parameter of debt/GDP was restricted to zero - the parameter has a zero value during the low debt/GDP regime, implying that during low-debt periods, government did not react to the debt/GDP ratio. In the

\footnotetext{
${ }^{6}$ Depending on the $\varphi$ and $\theta$ restrictions, the test also indicates the presence of two regimes in the UK. However, none of the tworegime specifications yielded successful models.

${ }^{7}$ It should be kept in mind that the sample sizes are not very large and that the JB test does not perform very well in smaller samples.
}

(C) 2012 The Clute Institute http://www.cluteinstitute.com/ 
UK, the $\varphi$ and $\theta$ parameters were restricted to $\varphi=-\theta$, indicating that in the low and high debt regimes (i.e., regimes 1 and 3), the government reacts to its debt/GDP ratio, but in the middle-debt regime (i.e., regime 2), it does not. This suggests that the UK government might consider the middle-debt regime to be a safe zone for the debt/GDP ratio. In the case of the US, the $\varphi$ of the cyclically-adjusted primary balance was restricted to zero. Setting $\varphi$ equal to zero, while leaving $\theta$ free, postulates that inertia is present in high-debt situations, but not in low-debt situations.

Table 1: Fiscal Reaction Functions (STR Estimates)

\begin{tabular}{|c|c|c|c|}
\hline & US & US & UK \\
\hline Dep variable & $\mathbf{C A P B / Y}$ & $\mathbf{C A P B} / \mathbf{Y}$ & $\mathbf{C A P B / Y}$ \\
\hline Restrictions $\varphi$ & CAPB/YP(-1); GL/Y(-1) & CAPB/YP(-1); GL/Y(-1) & \\
\hline Restrictions $\theta$ & YGAP(-1) & YGAP(-1) & \\
\hline Restrictions $\varphi=-\theta$ & & & $\begin{array}{c}\text { Const; } \\
\text { GL/Y(-1) }\end{array}$ \\
\hline Trans value of $s$ & 0.498 & 0.494 & $0.413 ; 0.539$ \\
\hline \multicolumn{4}{|l|}{ Linear part } \\
\hline Constant & $\begin{array}{l}-0.004 \\
(0.14)\end{array}$ & $\begin{array}{l}-0.004 \\
(0.083)\end{array}$ & $\begin{array}{c}-0.06 \\
(0.000)\end{array}$ \\
\hline$(\mathbf{B} / \mathbf{Y})_{t-1}$ & & & $\begin{array}{c}0.828 \\
(0.000)\end{array}$ \\
\hline$(D / Y)_{t-1}$ & & & $\begin{array}{c}0.132 \\
(0.000) \\
\end{array}$ \\
\hline$(\hat{\mathbf{y}})_{t-1}$ & $\begin{array}{c}0.143 \\
(0.091) \\
\end{array}$ & $\begin{array}{c}0.168 \\
(0.011) \\
\end{array}$ & $\begin{array}{c}0.031 \\
(0.455) \\
\end{array}$ \\
\hline \multicolumn{4}{|l|}{ Non-linear part } \\
\hline Constant & $\begin{array}{l}-0.083 \\
(0.002) \\
\end{array}$ & $\begin{array}{l}-0.079 \\
(0.000)\end{array}$ & $\begin{array}{c}-0.06 \\
(0.000) \\
\end{array}$ \\
\hline$(B / Y)_{t-1}$ & $\begin{array}{c}0.829 \\
(0.000) \\
\end{array}$ & $\begin{array}{c}0.785 \\
(0.000) \\
\end{array}$ & $\begin{array}{l}-0.133 \\
(0.066) \\
\end{array}$ \\
\hline$(\mathbf{D} / \mathbf{Y})_{t-1}$ & $\begin{array}{c}0.137 \\
(0.001) \\
\end{array}$ & $\begin{array}{c}0.132 \\
(0.000) \\
\end{array}$ & $\begin{array}{c}-0.132 \\
(0.000) \\
\end{array}$ \\
\hline$(\hat{\mathbf{y}})_{t-1}$ & & & $\begin{array}{c}-0.015 \\
(0.085) \\
\end{array}$ \\
\hline Adj R-sq & 0.74 & 0.82 & 0.86 \\
\hline Autocor(1) (p) & 0.28 & 0.47 & 0.92 \\
\hline Autocor(2) (p) & 0.23 & 0.55 & 0.96 \\
\hline JB value Normality (p) & 0.00 & 0.42 & $0.01(0.01)$ \\
\hline Remaining non-linearity & None & None & None \\
\hline Sample & $70-08$ & $70-07$ & $73-08$ \\
\hline
\end{tabular}

${ }^{\mathrm{a}}$ Values in ( ) represent $\mathrm{p}$ values.

The debt/GDP variable is the transition variable (the $s$ in Equation (10) above) in all models. Table 1 also presents $c$, which is the value of $s$, the transition variable (i.e., the debt/GDP ratio) at which the transition between regimes occurs. It indicates that in the US, the value is $49.4 \%$. The three regimes in the UK indicate that at low and high debt/GDP values (estimated to be below $41.3 \%$ and above $53.9 \%$ ), the UK government reacts sharply to its debt/GDP ratio while in between $41.3 \%$ and $53.9 \%$, it does not react, suggesting that the UK government considers 41.3\% and 53.9\% (implicitly or explicitly) as a safe zone for the debt/GDP ratio. Although the parameter for the debt/GDP ratio is rather large, when below $41.3 \%$, the effect of the intercept (interpreted as reflecting the implicit debt/GDP target; see Equation (8) above) dominates the effect of the lagged debt/GDP ratio and its parameter, thereby pushing the debt/GDP ratio back to the middle regime. When above $53.9 \%$, the opposite happens, also pushing the debt/GDP ratio back to the middle regime.

Regarding the fiscal reaction of the UK and US to the level of the debt/GDP ratio, note that once they enter the high debt/GDP regime, the parameter of the debt/GDP ratio is positive. In both the US and the UK, the parameter is 0.13 (regime 2 - the non-linear part of the model - for the US and regime 3 - the linear part of the model - in the UK). Also note that in the US, fiscal policy is countercyclical both during the low-debt and high-debt 
regimes. In the UK, fiscal policy seems to be acyclical in all regimes (seen from the statistically insignificant output gaps).

\section{CONCLUSION: SO WAS FISCAL POLICY SUSTAINABLE?}

Given the reaction of the UK and US governments to their debt/GDP ratios, were their respective fiscal policies sustainable? The Stationarity of the Debt/GDP Ratio section shows that for fiscal policy to be sustainable, where sustainability is defined as a non-explosive public debt/GDP ratio, $\alpha_{3} /\left(1-\alpha_{2}\right)>(r-g) /(1+g)$, in which case the ratios will be stationary, or $\alpha_{3} /\left(1-\alpha_{2}\right)=(r-g) /(1+g)$, in which case the ratios will be first difference stationary.

To calculate $r$ and $g$ data on the long-term government bond rate, the GDP deflator and the real economic growth rate (obtained from OECD, 2010) was used. $\alpha^{*}$ is then calculated as an average for the sample period used in estimating the regressions (with the corresponding real interest rate and real growth rate also reported in Tables 2). Table 2 uses the STR results for both the UK and US.

Using the parameters estimated above, as well as the detail regarding $\left(r_{t}-g_{t}\right) /\left(1+g_{t}\right)$, Table 2 shows that in both countries, fiscal policy was sustainable since in both cases $\alpha_{3} /\left(1-\alpha_{2}\right)>\left(r_{t}-g_{t}\right) /\left(1+g_{t}\right)$. Using Equation (8), the parameters estimated above and reported in Table 2 can also be used to calculate the values on which the debt/GDP and primary balance/GDP ratios converge. These are reported in Table 2.

Table 2: Equilibrium Debt/GDP and Primary Balance/GDP Ratios (STR and GMM)

\begin{tabular}{|l|c|c|}
\hline & UK & US \\
\hline $\boldsymbol{\alpha}_{\boldsymbol{1}}$ & -0.06 & -0.079 \\
\hline $\boldsymbol{\alpha}_{\mathbf{2}}$ & 0.83 & 0.79 \\
\hline $\boldsymbol{\alpha}_{3}$ & 0.132 & 0.132 \\
\hline $\boldsymbol{\alpha}_{\mathbf{3}} /\left(\boldsymbol{1}-\boldsymbol{\alpha}_{\mathbf{2}}\right)$ & 0.776 & 0.629 \\
\hline Sample period & $\mathbf{7 2 - 0 8}$ & $\mathbf{7 0 - 0 7}$ \\
\hline $\boldsymbol{\alpha}^{*}$ & 0.003 & 0.004 \\
\hline Real interest rate & 0.027 & 0.033 \\
\hline Real growth rate & 0.024 & 0.029 \\
\hline D/Y & $\mathbf{0 . 4 5 6}$ & $\mathbf{0 . 6 0 2}$ \\
\hline B/Y & $\mathbf{0 . 0 0 1}$ & $\mathbf{0 . 0 0 2}$ \\
\hline Threshold STR model & $0.413 ; 0.539$ & 0.494 \\
\hline
\end{tabular}

The results show that for the UK, the equilibrium debt/GDP values are $45.6 \%$ (with a corresponding primary balance/GDP value of $0.1 \%$ ). Note that the value lies within the middle regime. The results show that the US comes in higher at $60.2 \%$, with a primary balance/GDP ratio of $0.2 \%$. Thus, the results indicate tolerance for a higher debt/GDP ratio in the US than in the UK - something that is also reflected in their respective current stance with regard to public debt.

What the above results indicate is that if past behaviour is anything to go by, fiscal policy in the UK and the US is not unsustainable, even though these countries registered sharp increases in their public debt/GDP ratios following the 2008/9 financial and economic crisis. Note that for the US, the sample period includes the 1980s and early 1990s, when concern for public debt/GDP ratios was also high. These higher levels of concern followed the sharp increases in the US debt burden in the aftermath of the early 1980s recession and the Reagan administration's policy to reduce the tax burden in an effort to stimulate the economy. Thus, the analysis indicates that when seen against the evidence of past behaviour, the increased concern with the debt burden might not be fully justified. However, it is, of course, also the increased concern itself that spurs policy makers to take the necessary steps to adjust the deficit and ensure fiscal sustainability. Thus, in a rather paradoxical way, it is precisely because the concern encourages action that the concern is not fully justified. 


\section{AUTHOR INFORMATION}

Philippe Burger is Professor of Economics and Head of Department at the University of the Free State. He is currently also President-elect of the Economic Society of South Africa and coordinator of the Public Economics Working Group at Economics Research Southern Africa (ERSA). He is also Associate Editor of the South African Journal of Economics. E-mail: burgerp@ufs.ac.za or burgph@gmail.com

\section{REFERENCES}

1. Bohn, H. (2010). The Economic Consequences of Rising U.S. Government Debt: Privileges at Risk. Retrieved from: http://econ.ucsb.edu/ bohn

$2 . \quad$ _. (2007). Are stationary and cointegration restrictions really necessary for the intertemporal budget constraint? Journal of Monetary Economics, 54 1837-47

$3 . \quad$ (1998). The behaviour of US public debt and deficits. The Quarterly Journal of Economics, 113 (3) 949-63.

4. (1995). The sustainability of budget deficits in a stochastic economy. Journal of Money, Credit and Banking, 27(1) 257-271

5. Cecchetti, G, Mohanty, M.S. and Fabrizio, Z. (2010). The future of public debt: prospects and implications. BIS Working Papers, no. 300.

6. De Mello, L. (2005). Estimating a fiscal reaction function: The case of debt sustainability in Brazil. OECD Economics Department Working Paper No. 423. OECD, Paris.

7. Favero, C and Marcellino, M. (2005). Modelling and forecasting fiscal variables for the Euro Area. Oxford Bulletin of Economics and Statistics, 67 (Supplement (2005) 0305-9049) 755-83.

8. Gali, J. and Perotti, R. (2003). Fiscal policy and monetary integration in Europe. CEPR Discussion Paper No. 3933, Centre for Economic Policy Research, London.

9. Girouard, N and André, C. (2005). Measuring cyclically-adjusted budget balances for OECD countries. Economics Department Working Papers, no. 434. OECD, Paris.

10. OECD. (2010). OECD database - Economic Outlook 86. OECD intranet.

11. OECD. (2009). Economic Surveys: Japan 2009. Retrieved from: http://dx.doi.org/10.1787/725342645833

12. Pindyck, R.S. and Rubinfeld, D.L. (1998). Econometric models and econometric forecasts. $4^{\text {th }}$ ed. McGraw-Hill International Edition, Boston.

13. Taylor, J. B. (2000). Reassessing discretionary fiscal policy. Journal of Economic Perspectives, 14(3): 2136.

14. Teräsvirta, T. (2004). Smooth transition regression modelling. In Lütkepohl, H. and Krätzig, M. (Ed). 2004. Applied time series econometrics. Cambridge: Cambridge University Press. 